\title{
A diagramatic scale to quantify severity of antracnose in Rubus glaucus Benth
}

\author{
Paula Andrea González Patiño ${ }^{1 *}$ (iD) Gloria Edith Guerrero Álvarez ${ }^{1}$ (iD Liliana Isaza Valencia ${ }^{2}$ iD
}

${ }^{1}$ Laboratorio de Oleoquímica, Faculta de Tecnologías, Universidad Tecnológica de Pereira (UTP), Carrera 27, No. 10-02, Barrio Álamos,
660003, Pereira, Risaralda, Colombia. E-mail: paula.gonzalez@ utp.edu.com."Corresponding author.
${ }^{2}$ Laboratorio de Biodiversidad y Biotecnología, Faculta de Ciencias Ambientales, Universidad Tecnológica de Pereira (UTP), Pereira, Risaralda, Colombia.

ABSTRACT: Rubus glaucus Benth, commonly referred to as mora de Castilla, is affected by Colletotrichum acutatum, as it induces anthracnose in many of the plant organs. Generally, it affects the fruits during the post-harvest phase and damages them, causing economic losses due to the poor crop quality. At present, no standardized methods are available for this pathosystem that can be used to characterize quantitatively the epidemic and to permit the prediction and comparison of the disease management techniques. In this research, we proposed a logarithmic diagrammatic scale of the severity of anthracnose induced by $C$. acutatum in the fruits of the thornless variety of $R$. glaucus Benth. This scale is constructed on the adjustment of the Weber-Fechner law and includes six classes, viz., 0\%, 1-6\%, 7-25\%, 26-50\%, 51-75\%, 76-100\%. The scale was validated using 14 evaluators, which entailed measuring the affected fruits with and without utilizing the scale; this improved the precision, accuracy and reproducibility of the calculations whenever the scale was used. We concluded that the scale proposed can be used to assess the severity of anthracnose induced by the fungus in the R. glaucus Benth fruits.

Key words: Colletotrichum acutatum, Epidemiology, pathometry, phytopathometry, Rubus glaucus Benth.

Uma escala diagramática para quantificar a severidade da antracnose em Rubus glaucus Benth

RESUMO: Mora de Castilla (Rubus glaucus Benth) é afetado por Colletotrichum acutatum, causando antracnose em órgãos diferentes da planta. Nos frutos geralmente é em pós-colheita, causando danos que geram perdas econômicas relacionadas com a qualidade das culturas. Ainda não existem para esse patossistema métodos padronizados para caracterizar quantitativamente a epidemia e que pode prever e comparar os métodos de manejo da doença. Por esta razão, neste trabalho foi criada uma escala logarítmica diagramática da severidade da antracnose causada pelo fungo C. acutatum em frutos de R. glaucus Benth com base na lei de Weber-Fechnere composto por 6 niveis: $0 \%$, $1-6 \%, 7-25 \%, 26-50 \%, 51-75 \%$ e 76-100\%. A escala foi validada por 14 evaluadores, fazendo mediçóes de frutos afetados com e sem o uso da escala, que mostrou melhor precisão, exatitude e reproducibilidade nas avaliações em que o uso da escala foi feito. Isto permite concluir que a escala proposta pode ser usada na estimação da severidade da antracnose causada em frutos de R. glaucus Benth.

Palavras-chave: Colletotrichum acutatum, epidemiologia, patometrí, fitotopatometría, Rubus glaucus Benth.

\section{INTRODUCTION}

In Colombia, $R$. glaucus Benth, commonly referred to as mora de Castilla, is the most popular species of Rubus to be cultivated. Colombia produces approximately 116000 tons from a total cultivated area of 13200 ha (CARVALHO \& BETANCOUR, 2015). As this fruit is highly perishable, storage poses problems (VILLEGAS \& ALBARRACÍN, 2016). The problem is linked to the physiological, ecological or environmental factors (ESTUPIÑAN et al, 2011), and particularly because this fruit plays host to a wide spectrum of microorganisms, of which C. acutatum is the principal phytopathogen.

It is well known that $C$. acutatum damages several plant organs like stems, leaves, fruits and flowers. Although, it can attack fruits, mainly during the late stages of maturity, it occurs mainly in the postharvest phase as anthracnose (RUEDA et al 2013). At this time the fungus first induces latent infections, by infecting the immature fruit and enters a dormant state until the fruit attains full maturity and then it recommences its development. The plant exhibits the characteristic symptoms of brown lesions that get darker over time (FORCELINI et al., 2018). Diseases cause huge economic losses in terms of poor crop quality, and minimize drastically the competitiveness in complying with the export regulations (BETANCUR, 2014). This significantly governs the decision to conduct research on this pathogen 
as a priority, utilizing tools which can facilitate its diagnosis and evaluate possible treatments.

Normally, for any disease-related diagnosis, knowledge regarding its intensity is essential, either by incidence or severity. For such types of evaluation standardized, reproducible, accurate, and precise methods are required. Only then can all kinds of variability be avoided when different evaluators are used to measure the same characteristics of the material (PRICE et al., 2016), (NUÑEZ et al., 2017). The most popularly used technique is the diagrammatic scales method because it is a direct and simple measurement process to assess disease severity (ORTEGA et al., 2016). In this method, the plant tissue area affected by the disease symptoms is delimited in a percentage quantification, supported by graphical tools that appreciably improve the measurements. This method makes it possible to know more objectively and precisely the disease progression (BELAN et al., 2014). Generally, the diagrammatic scales of severity in the plants must satisfy three criteria: i) the upper and lower limits of severity observed in the field must be defined ii) the symptoms represented must be identical to the ones visible in the field, and iii) their levels of intermediate gravity must be interpreted based on the Weber-Fechner stimulus-response law modified by Horsfall and Barratt in 1945 (CAMPBELL \& MADDEN, 1990). Similarly, these scales must be validated before being proposed as a standard method of quantification, to ensure that they are accurate, precise, and repeatable (CAPUCHO et al., 2011).

In order to propose a method of measuring the pathogenicity of C. acutatum in the spineless variety of $R$. glaucus Benth, it was established a logarithmic diagrammatic scale of severity based on the WeberFechner method modified by Horsfall-Barratt.

\section{MATERIALS AND METHODS}

Vegetal material. Fruits of the spineless variety of $R$. glaucus Benth were collected in Santa Rosa de Cabal, Risaralda, Colombia. These were selected and segregated based on the criteria of quality and maturity level according to the Colombian technical standard NTC 4106 (VILLEGAS \& ALBARRACÍN, 2016). While being transported the samples were maintained at $4{ }^{\circ} \mathrm{C}$, and later refrigerated at $4{ }^{\circ} \mathrm{C}$ in the laboratory.

Inoculation of fruits. Initially we carry out a surface disinfection of the fruits. Subsequently, the fruits were inoculated with a suspension of $1 \times 106$ spores/ml. Samples were kept in chambers under incubation conditions at room temperature and a relative humidity of $90-100 \%$. Fruits used as control treatments, were subjected to similar procedures where they were disinfected, and then sterile distilled water was sprinkled on them.

Evaluation of severity patterns of the disease. Photographic tracking was done and the progress of the disease was recorded. A Nikon digital camera, model D610 was used to capture the images. The software ImageJ was used to measure the areas of lesions and the fruit sizes were noted. From these findings, the relationship between the infection manifested, in terms of the total area of the fruits, and the diagrammatic logarithmic scale which represents the percentage of damage the fungus caused in the fruit at different stages was developed. The diagrammatic logarithmic scale includes the descriptive key and photographic representation related to each class or category of measurement. Images showing percentages of severity as near as possible to the midpoints of each class were selected, while attempting to preserve the original color to the best possible degree.

Validation of the diagrammatic scale of severity and statistical analysis. The accuracy and reproducibility of the proposed severity scale was established based on the description of (ORTEGA et al., 2016), but with some alterations. To accomplish this, two evaluations were performed under laboratory conditions, based on the parameters of visual evaluation. A set of 23 photographs showing different degrees of severity, as well as the scale, were colorprinted on high-quality photographic paper in lettersized sheets. Results obtained were compared with those gotten using the ImageJ software.

With the help of 14 evaluators (agronomists, biologists, phytopathologists and research assistants) the evaluations were carried out over two sessions. In the first session two evaluations were performed, one without using the scale and the other using the scale. After eight days, in the second session, the evaluators utilized the scale. With the estimated measurements using the scale and the real values of severity derived with the program, it was performed a simple linear regression analysis for each evaluator data in order to calculate the accuracy $\left(\mathrm{R}^{2}\right)$. Accuracy was confirmed with the student t test applied to the intercept $\left(\beta_{0}\right)$ to verify the hypothesis $\mathrm{H}_{0}: \beta_{0}=0$, and the slope of the line $\left(\beta_{1}\right)$ to verify the hypothesis $H_{1}: \beta_{1}=0$. Reproducibility of the scale was assessed using the coefficients of determination of the linear regressions between the severity determined by two evaluators. The calculations were made using the BM SPSS Statistics 23.0 program. 


\section{RESULTS}

Diagrammatic logarithmic scale of severity. A total of six classes were determined, which included the following intervals: $1=$ healthy; $2=$ $1-6 \% ; 3=7-25 \% ; 4=26-50 \% ; 5=51-75 \%$; and $6=$ $76-100 \%$. (Figure 1).

Validation. Using the data drawn from each evaluator, the linearity coefficients were calculated (Table 1).The evaluators experienced a great deal of difficulty when the scale was not available to them, this was evident from the low precision of most of the evaluators, with $\mathrm{R}^{2}$ falling between 0.23 and 0.95 , and average of $\mathrm{R}^{2}=0.73 \pm 0.19$. On the contrary, when the scale was used results showed a remarkable improvement for all the evaluators, revealing variations for $\mathrm{R}^{2}$ between 0.84 and 0.97 , with an average of $0.91 \pm 0.03$ for the first evaluation, and between 0.77 and 0.98 , with an average of 0.88 \pm 0.06 for the second. Regarding accuracy, when the evaluators didn't use the scale, intercept values $\beta_{0}$ were reported to be significantly different from zero, producing rejection in most instances. However, for slope $\beta_{1}$, only one of the values showed significant difference compared to one. But when the evaluators used the scale, more accurate results were obtained in both tests. For evaluations one and two, coefficient $\beta_{0}$ revealed that $3.84 \%$ of the data were significantly

\begin{tabular}{|c|c|c|c|}
\hline Class & Graphic & $\begin{array}{c}\text { Degree of } \\
\text { Severity in\% }\end{array}$ & Description of damage \\
\hline 1 & & $0 \%$ & $\begin{array}{l}\text { No appearance of necrosis or acervuli is noticed on the tissue } \\
\text { surface; therefore, it is considered } 0 \% \text { of the total area of the fruit. }\end{array}$ \\
\hline 2 & & $1-6 \%$ & $\begin{array}{l}\text { The signs of progressive necrosis are noted, with or without the } \\
\text { presence orange-salmon (acervuli) produced on the tissue surface, } \\
\text { affecting around } 6 \% \text { of the total area of the fruit. The remaining } \\
\text { portion of the fruit starts to lose the intense red color and } \\
\text { becomes pale red. }\end{array}$ \\
\hline 3 & & $7-25 \%$ & $\begin{array}{l}\text { The signs of progressive necrosis cause the color to intensify to a } \\
\text { deeper brown, with or without the production of orange-salmon } \\
\text { (acervuli) on the tissue surface, covering up to } 25 \% \text { of the total } \\
\text { area of the fruit. }\end{array}$ \\
\hline 4 & & $26-50 \%$ & $\begin{array}{l}\text { The signs of progressive necrosis induce color intensification to a } \\
\text { darker brown, with or without the production of orange-salmon } \\
\text { (acervuli) on the tissue surface, extending to approximately } 25 \% \text { of } \\
\text { the total area of the fruit. }\end{array}$ \\
\hline 5 & & $51-75 \%$ & $\begin{array}{l}\text { The signs of progressive necrosis deepen the color to a darker } \\
\text { brown, with or without the production of orange-salmon (acervuli) } \\
\text { on the tissue surface, covering up to } 75 \% \text { of the total area of the } \\
\text { fruit. The remaining part the fruit surface shows a gradual color } \\
\text { change from pale pink to yellowish rose. }\end{array}$ \\
\hline 6 & & $76-100 \%$ & $\begin{array}{l}\text { The signs of progressive necrosis intensify the color to a dark } \\
\text { brown, with or without the orange-salmon (acervuli) being } \\
\text { produced on the tissue surface, extending to up to } 100 \% \text { of the } \\
\text { total area of the fruit. During this process, the color of the } \\
\text { remaining surface slowly changes from yellowish to light brown, } \\
\text { until it is entirely dark brown. }\end{array}$ \\
\hline \multicolumn{4}{|c|}{$\begin{array}{l}\text { Figure } 1 \text { - Logarithmic diagram of severity and descriptive key to assess the anthracnose } \\
\text { caused by C. acutatum and } R \text {. glaucus Benth. }\end{array}$} \\
\hline
\end{tabular}

Ciência Rural, v.49, n.4, 2019. 
Table 1 - Coefficient of determination $\left(\mathrm{R}^{2}\right)$, intercept $\left(\beta_{0}\right)$, and slope $\left(\beta_{1}\right)$ of the linear regression equation related to the estimates of the severity of the anthracnose caused by $C$. acutatum in the spineless variety of $R$. glaucus Benth, between the evaluators in pairs, with and without the use of the diagrammatic scale.

\begin{tabular}{|c|c|c|c|c|c|c|c|c|c|}
\hline \multirow{3}{*}{ Evaluator } & \multirow{2}{*}{\multicolumn{3}{|c|}{-----Coefficients Without Scale----- }} & \multicolumn{6}{|c|}{ 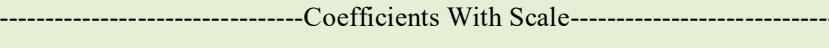 } \\
\hline & & & & \multicolumn{2}{|c|}{ Validation 1} & \multicolumn{4}{|c|}{ 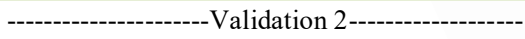 } \\
\hline & $\beta_{0}$ & $\beta_{1}$ & $\mathrm{R}^{2}$ & $\beta_{0}$ & $\beta_{1}$ & $\mathrm{R}^{2}$ & $\beta_{0}$ & $\beta_{1}$ & $\mathrm{R}^{2}$ \\
\hline e1 & 8.15 & 1.03 & 0.92 & 6.01 & 0.99 & 0.93 & 2.95 & 1.03 & 0.98 \\
\hline e2 & 18.76 & 0.86 & 0.79 & 8.76 & 0.96 & 0.90 & 9.98 & 0.90 & 0.88 \\
\hline e3 & 17.57 & 0.92 & 0.83 & 7.42 & 0.99 & 0.89 & 17.53 & 0.81 & 0.81 \\
\hline e4 & 20.59 & 1.02 & 0.73 & 6.78 & 0.98 & 0.91 & 10.64 & 1.00 & 0.88 \\
\hline e5 & 16.63 & 0.92 & 0.85 & 7.67 & 0.97 & 0.88 & 4.80 & 0.99 & 0.92 \\
\hline e6 & 16.10 & 1.12 & 0.67 & -0.03 & 1.02 & 0.97 & 3.00 & 1.08 & 0.89 \\
\hline e7 & 30.41 & 0.76 & 0.53 & 10.08 & 0.91 & 0.92 & 10.56 & 0.96 & 0.91 \\
\hline e8 & 10.42 & 0.96 & 0.87 & 4.30 & 1.01 & 0.93 & 9.37 & 0.79 & 0.77 \\
\hline e9 & 29.46 & 0.76 & 0.56 & 5.17 & 0.98 & 0.84 & 13.81 & 0.92 & 0.78 \\
\hline e10 & 46.03 & 0.62 & 0.23 & 1.88 & 1.06 & 0.93 & 4.46 & 0.92 & 0.86 \\
\hline e11 & 1.38 & 0.97 & 0.82 & 4.00 & 0.98 & 0.94 & 7.60 & 0.97 & 0.91 \\
\hline e12 & 5.32 & 0.98 & 0.95 & 4.73 & 0.99 & 0.91 & 3.92 & 0.97 & 0.95 \\
\hline e13 & 9.86 & 0.87 & 0.83 & 5.83 & 0.95 & 0.89 & 6.92 & 0.99 & 0.90 \\
\hline e14 & 1.33 & 0.94 & 0.72 & 3.48 & 1.00 & 0.90 & 3.96 & 1.01 & 0.88 \\
\hline Average & 16.57 & 0.91 & 0.73 & 5.43 & 0.98 & 0.91 & 7.82 & 0.95 & 0.88 \\
\hline Std. Dev. & 12.38 & 0.13 & 0.19 & 2.69 & 0.03 & 0.03 & 4.39 & 0.08 & 0.06 \\
\hline
\end{tabular}

different from zero, while for coefficient $\beta$, no data were observed to be significantly different from one. From these results it is clear that most of the evaluators gave acceptable degrees of accuracy and precision. Besides, these conditions were seen to improve when the scale was used, the exception being for evaluators e3, e7 and e9, whose even with the use of the scale did not achieve the expected results.

Figure 2 shows the residuals (absolute error in the estimated severity vs. real severity). A total of 966 data were analyzed (14 evaluators, three evaluations, 23 fruits). The highest absolute errors were achieved when the scale was not used, demonstrating a remarkable tendency to undervalue the degree of disease severity (upper section of Figure 2). In the evaluation without using the scale, an absolute error range of $-100 \%$ to $70 \%$ was reported, while in the instance of evaluations one and two (with scale), range was seen to be from $-42.25 \%$ to $45.63 \%$ and from $-65 \%$ at $63.63 \%$, respectively (intermediate and lower sections of Figure 2, respectively). The last two cases retained the tendency to under rate the severity; although, it was less noticeable than in the case of the evaluation without the scale.

Regarding reproducibility, in the cases where the scale was not used, the $\mathrm{R}^{2}$ values were between 0.06 and 0.94 with an average of 0.62 , and with $29 \%$ of the data above 0.80 . Conversely, in the first evaluation with the use of the scale the $\mathrm{R}^{2}$ values were from 0.70 to 0.96 with an average of 0.87 , and with $96 \%$ of the data above 0.80 . In the second evaluation with the use of the scale the $\mathrm{R}^{2}$ values were from 0.61 to 0.97 with an average of 0.867 and with $81 \%$ of the data above 0.80 (Table 2). This shows that the data where the scale was used exhibit high reproducibility and that the $\mathrm{R}^{2}$ values increase with the use of the scale.

\section{DISCUSSION}

The number of classes selected for the logarithmic scale constructed in this study is within the ranges that other researchers have considered suitable and is in concordance with most of the diagrammatic logarithmic scales which are in the range of five to eight classes (BOITO et al., 2013). In addition, other authors have reported satisfactory results while employing the established severity intervals for this scale (LADD et al., 2011), (BUFFARA et al., 2014), (NICOLI et al., 2015).

Many types of diagrammatic scales of severity available are based on measurements, including the logarithmic, linear approximations or totally arbitrary ones (NICOLI et al., 2015). However, 


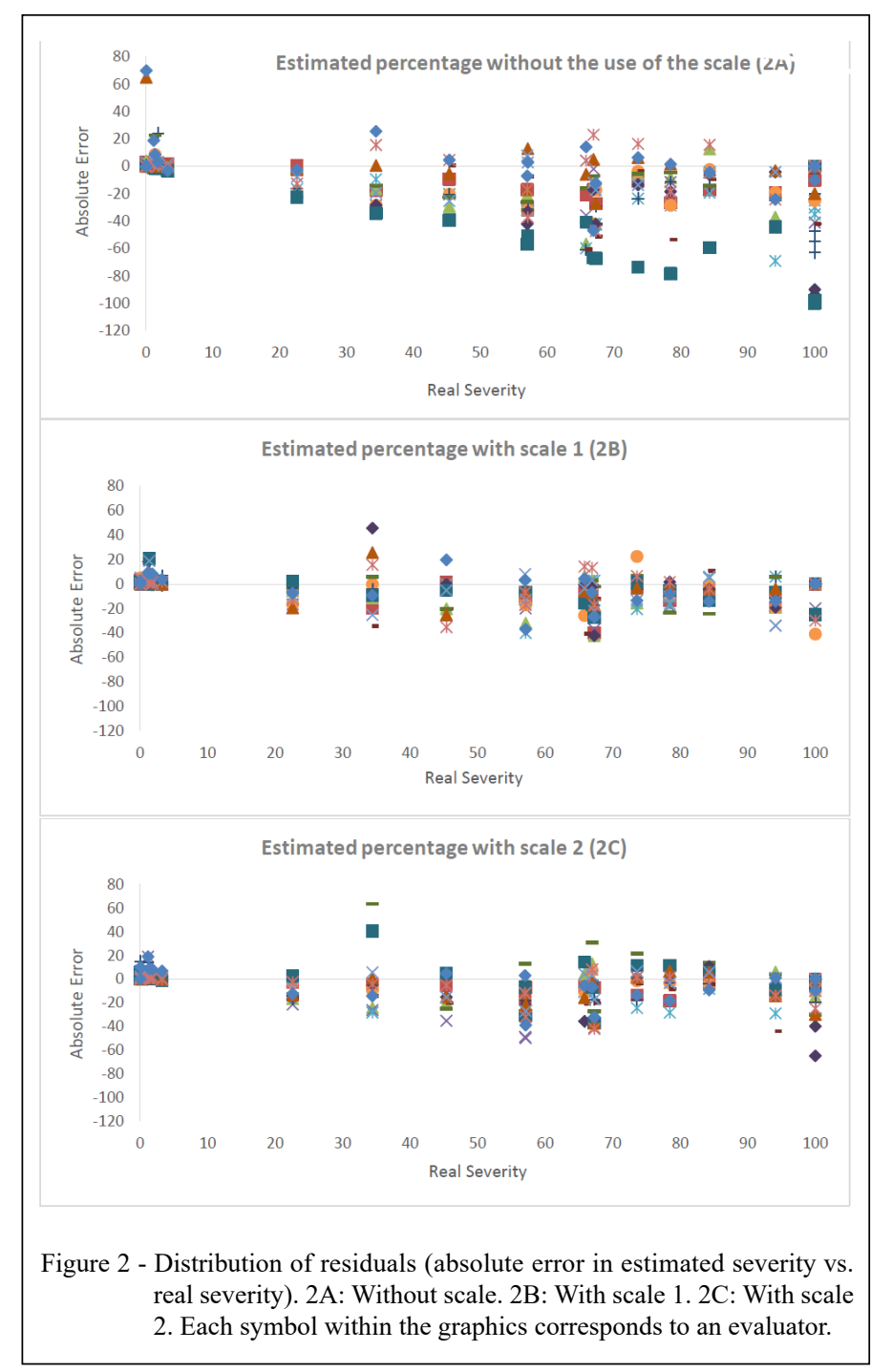

there is no consensus regarding the superiority of any particular methods; although, there is evidence for the visual observations being naturally logarithmic. For this last reason the diagrammatic logarithmic model was selected for this scale. This model is based on the adjustment of the Weber-Fechner method modified by Horsfall \& Barratt in 1945 .

When the accuracy of the evaluators assessed from the hypotheses $\mathrm{H}_{0}: \beta_{0}=0$ and $\mathrm{H}_{1}: \beta_{1}=$ 0 is considered, more rejections were observed in the cases when no scale was used. Similar behavior was observed with the correlation coefficient $\mathrm{R}^{2}$ due to the fact that the average values obtained using the scale in the first and second tests showed an improvement of the order of $24 \%$ and $20 \%$ respectively, when compared to the value obtained without using the scale.
According to the criteria employed by ORTEGA et al., (2016), absolute error values of up to $5 \%$ are accepted as excellent, while values of up to $10 \%$ are considered acceptable. In the present study, when the scale was not used $55 \%$ of the data fell within the range of $-10 \%$ and $10 \%$, while in the case when the scale was used $73.3 \%$ and $68 \%$ of the data fell within the range of -10 and 10 in the first and second evaluations, respectively. From these results it is evident that the number of data considered acceptable becomes significantly higher when the scale is used.

According to ORTEGA et al., (2016), most of the research conducted on the agricultural pathosystems showed that when the diagrammatic scales are not used, there is a tendency to overestimate 
Table 2 - Coefficient of determination $\left(\mathrm{R}^{2}\right)$ of the linear regression equation related to estimates of the severity of the C. acutatum induced anthracnose in the spineless variety of $R$. glaucus Benth, between paired evaluators, with and without the diagrammatic scale.

\begin{tabular}{|c|c|c|c|c|c|c|c|c|c|c|c|c|c|}
\hline Evaluators & E2 & E3 & E4 & E5 & E6 & E7 & E8 & E9 & E10 & E11 & E12 & E13 & E14 \\
\hline \multicolumn{14}{|c|}{ out sc } \\
\hline E1 & 0.878 & 0.903 & 0.810 & 0.914 & 0.635 & 0.560 & 0.945 & 0.563 & 0.300 & 0.792 & 0.912 & 0.857 & 0.702 \\
\hline E2 & & 0.897 & 0.889 & 0.870 & 0.689 & 0.529 & 0.897 & 0.521 & 0.172 & 0.719 & 0.776 & 0.834 & 0.612 \\
\hline E3 & & & 0.771 & 0.834 & 0.638 & 0.484 & 0.908 & 0.645 & 0.279 & 0.797 & 0.808 & 0.852 & 0.630 \\
\hline E4 & & & & 0.799 & 0.616 & 0.671 & 0.817 & 0.277 & 0.095 & 0.626 & 0.711 & 0.728 & 0.635 \\
\hline E5 & & & & & 0.672 & 0.601 & 0.880 & 0.619 & 0.311 & 0.721 & 0.846 & 0.757 & 0.686 \\
\hline E6 & & & & & & 0.590 & 0.640 & 0.411 & 0.187 & 0.521 & 0.634 & 0.584 & 0.401 \\
\hline E7 & & & & & & & 0.521 & 0.167 & 0.058 & 0.460 & 0.530 & 0.479 & 0.466 \\
\hline E8 & & & & & & & & 0.555 & 0.257 & 0.789 & 0.870 & 0.880 & 0.679 \\
\hline E9 & & & & & & & & & 0.480 & 0.575 & 0.540 & 0.518 & 0.397 \\
\hline E10 & & & & & & & & & & 0.242 & 0.270 & 0.211 & 0.217 \\
\hline E11 & & & & & & & & & & & 0.799 & 0.740 & 0.823 \\
\hline E12 & & & & & & & & & & & & 0.778 & 0.702 \\
\hline E13 & & & & & & & & & & & & & 0.624 \\
\hline \multicolumn{14}{|c|}{ 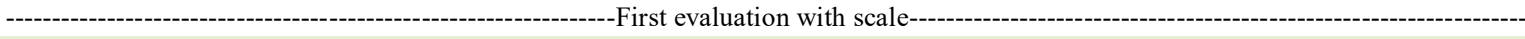 } \\
\hline E1 & 0.955 & 0.949 & 0.854 & 0.887 & 0.945 & 0.910 & 0.863 & 0.817 & 0.943 & 0.884 & 0.947 & 0.841 & 0.943 \\
\hline E2 & & 0.929 & 0.859 & 0.845 & 0.910 & 0.865 & 0.845 & 0.823 & 0.891 & 0.903 & 0.931 & 0.901 & 0.931 \\
\hline E3 & & & 0.823 & 0.943 & 0.899 & 0.887 & 0.821 & 0.834 & 0.876 & 0.885 & 0.937 & 0.843 & 0.899 \\
\hline E4 & & & & 0.790 & 0.895 & 0.872 & 0.891 & 0.738 & 0.880 & 0.850 & 0.835 & 0.823 & 0.882 \\
\hline E5 & & & & & 0.889 & 0.861 & 0.839 & 0.843 & 0.861 & 0.874 & 0.843 & 0.823 & 0.826 \\
\hline E6 & & & & & & 0.941 & 0.918 & 0.823 & 0.964 & 0.937 & 0.910 & 0.867 & 0.893 \\
\hline E7 & & & & & & & 0.863 & 0.702 & 0.908 & 0.848 & 0.910 & 0.794 & 0.819 \\
\hline E8 & & & & & & & & 0.799 & 0.916 & 0.914 & 0.810 & 0.904 & 0.819 \\
\hline E9 & & & & & & & & & 0.826 & 0.889 & 0.748 & 0.870 & 0.787 \\
\hline E10 & & & & & & & & & & 0.897 & 0.895 & 0.867 & 0.885 \\
\hline E11 & & & & & & & & & & & 0.854 & 0.929 & 0.846 \\
\hline E12 & & & & & & & & & & & & 0.834 & 0.912 \\
\hline E13 & & & & & & & & & & & & & 0.805 \\
\hline & & & & & -----Se & nd eval & tion wit & scale--- & -------- & ------- & -------- & ------- & ------- \\
\hline E1 & 0.880 & 0.834 & 0.941 & 0.920 & 0.901 & 0.937 & 0.716 & 0.748 & 0.839 & 0.897 & 0.943 & 0.891 & 0.893 \\
\hline E2 & & 0.956 & 0.885 & 0.935 & 0.878 & 0.884 & 0.764 & 0.803 & 0.830 & 0.937 & 0.947 & 0.935 & 0.904 \\
\hline E3 & & & 0.880 & 0.884 & 0.863 & 0.874 & 0.707 & 0.764 & 0.790 & 0.885 & 0.908 & 0.891 & 0.867 \\
\hline E4 & & & & 0.920 & 0.874 & 0.933 & 0.616 & 0.681 & 0.781 & 0.859 & 0.891 & 0.880 & 0.910 \\
\hline E5 & & & & & 0.927 & 0.931 & 0.780 & 0.806 & 0.895 & 0.956 & 0.947 & 0.972 & 0.949 \\
\hline E6 & & & & & & 0.914 & 0.724 & 0.787 & 0.814 & 0.927 & 0.908 & 0.876 & 0.920 \\
\hline E7 & & & & & & & 0.723 & 0.752 & 0.826 & 0.920 & 0.920 & 0.908 & 0.872 \\
\hline E8 & & & & & & & & 0.746 & 0.889 & 0.852 & 0.861 & 0.819 & 0.707 \\
\hline E9 & & & & & & & & & 0.764 & 0.859 & 0.823 & 0.876 & 0.743 \\
\hline E10 & & & & & & & & & & 0.903 & 0.922 & 0.918 & 0.828 \\
\hline E11 & & & & & & & & & & & 0.958 & 0.945 & 0.891 \\
\hline E12 & & & & & & & & & & & & 0.949 & 0.916 \\
\hline E13 & & & & & & & & & & & & & 0.904 \\
\hline
\end{tabular}

the disease, while a fewer number of research works stated that the tendency is inclined to underestimate the disease. In this study, when the scale was not used, $61 \%$ of the evaluations were underestimations of the disease, while $17 \%$ were overestimations. For the first evaluation made with the scale $48 \%$ of the evaluators underestimated the disease, while $27 \%$ overestimated it. For the second evaluation with the scale, $48 \%$ of the evaluators underestimated the disease, while $31 \%$ overestimated it. The absolute 
error values showed the tendency of the evaluators to underrate the disease with and without the use of the scale, with higher error values in the latter case. Evaluations that underestimate the disease decrease when the scale is used, thus escalating the overestimation. This means that, with the use of the scale, in both assessments, the underestimation and overestimation of the disease tended to the same values approximately, thus allowing a higher percentage of absolute errors to fall within the range considered as acceptable ( -10 to $10 \%)$.

With respect to reproducibility, the $\mathrm{R}^{2}$ correlation obtained using the scale in the first and second tests demonstrated an improvement of $40 \%$ and $39 \%$ respectively, when compared to the value obtained without of the scale.

\section{CONCLUSION}

According to the present research the diagrammatic logarithmic scale of severity constructed for Colletotrichum acutatum induced anthracnose in the fruits of the spineless variety of Rubus glaucus Benth can be successfully implemented as a standardized method, which is reproducible, accurate, and precise in assessing the damages caused by this disease.

\section{ACKNOWLEDGEMENTS}

The authors are grateful to General System of Royalties of the Government of Colombia, South America, for financial support.

\section{DECLARATION OF CONFLICT OF INTERESTS}

The authors declare no conflict of interest. The founding sponsors had no role in the design of the study; in the collection, analyses, or interpretation of data; in the writing of the manuscript, and in the decision to publish the results.

\section{AUTHORS' CONTRIBUTIONS}

González and Guerrero conceived and designed experiments. González performed the experiments and carried out the lab analyses. González performed statistical analyses of experimental data. González and Guerrero interpreted the data. Isaza reviewed the information. González prepared the draft of the manuscript. All authors critically revised the manuscript and approved of the final version.

\section{REFERENCES}

BELAN, L. L. et al. Diagrammatic scale for assessment of bacterial blight in coffee leaves. Journal of Phytopathology, v. 162, n. 11-12, p. 801-810, dec. 2014. Available from: <http://doi.wiley. com/10.1111/jph.12272>. Accessed: Mar. 15, 2017. doi: 10.1111/ jph.12272.

BETANCUR, E. Manual técnico del cultivo de mora bajo buenas prácticas agrícolas. Medellín, Colombia: Gobernación de Antioquia, Secretaría de agricultura y desarrollo rural, 2014. Available from: https://searchworks.stanford.edu/view/11744762. Accessed: Mar. 18, 2017.

BOITO, G. T. et al. Development and validation of a scale to evaluate defoliating caterpillars damage in soybean (Glycine max $L$.), for South of the province of Cordoba. Revista de la Facultad de Ciencias Agrarias. Universidad Nacional de Cuyo, v. 45, n. 1, p. 91-104, 2013. Available from: <http://bdigital.uncu.edu.ar/ objetos digitales/5046/t45-01-08-boito.pdf $>$. Accessed: Feb. 23, 2017.

BUFFARA, C. R. S. et al. Elaboration and validation of a diagrammatic scale to assess downy mildew severity in grapevine. Ciência Rural, v. 44, n. 8, p. 1384-1391, 2014. Available from: $<$ http://www.scielo.br/pdf/cr/v44n8/0103-8478-cr-44-08-01384. pdf $>$. Accessed: Mar. 18, 2017. doi: 10.1590/0103$8478 \mathrm{cr} 20131548$.

CAMPBELL, C.; MADDEN, L. Monitoring epidemics: diseases. In: Introduction to plant disease epidemiology. New York, USA. John Wiley \& Sons, 1990, p. 107-128.

CAPUCHO, A. S. et al. Development and validation of a standard area diagram set to estimate severity of leaf rust in Coffea arabica and C. canephora. Plant Pathology, v. 60, n. 6, p. 1144-1150, 2011. Available from: $<$ https://onlinelibrary.wiley.com/doi/abs/10 $.1111 / \mathrm{j} .1365-3059.2011 .02472 . x>$. Accessed: May, 05, 2017. doi: 10.1111/j.1365-3059.2011.02472.x.

CARVALHO, C. P.; BETANCOUR, J. A. Quality characterization of Andean blackberry fruits (Rubus glaucus Benth.) in different maturity stages in Antioquia. Agronomía Colombiana, v. 33, n. 1, p. 74-83, jun. 9, 2015. Available from: $<$ http://www.revistas.unal. edu.co/index.php/agrocol/article/view/47132>. Accessed: Jun. 23, 2017. doi: 10.15446/agron.colomb.v33n1.47132.

ESTUPIÑAN, D. C. et al. Antioxidant activity, total phenolics content, anthocyanin, and color stability of isotonic model beverages colored with Andes berry (Rubus glaucus Benth) anthocyanin powder. Journal of Food Science, v. 76, n. 1, p 26-34, 2011. Available from: https://onlinelibrary.wiley.com/doi/ full/10.1111/j.1750-3841.2010.01935.x. Accessed: Sep. 2, 2018. doi: $10.1111 / \mathrm{j} .1750-3841.2010 .01935 . \mathrm{x}$.

FORCELINI, B. B. et al. Fitness, Competitive ability, and mutation stability of isolates of Colletotrichum acutatum from strawberry resistant to QoI fungicides. Phytopathology, v. 108, n. 4, p. $462-$ 468, apr 13. 2018. Available from: < https://apsjournals.apsnet.org/ doi/10.1094/PHYTO-09-17-0296-R>. Accessed: Jun. 27, 2017. doi:10.1094/PHYTO-09-17-0296-R

LADD, I. et al. Ozone-induced foliar injury field guide. NASA Publication NP-2011-03-355-LaRC, 2011. 144p. Available from: https://science-edu.larc.nasa.gov/ozonegarden/pdf/Bio-guidefinal-3 15 11.pdf. Accessed: Apr. 18, 2017.

NICOLI, A. et al. Validação de escala diagramática para quantificação da severidade da antracnose do colmo do milho. Ciência Rural, v. 45, n. 10, p. 1720-1726, Jun. 19, Jun. 2015. Available from: <http://www.scielo.br/pdf/cr/2015nahead/1678- 
4596-cr-0103_8478cr20141510.pdf>. Accessed: Feb, 10, 2017. doi:10.1590/0103-8478cr20141510.

NUÑEZ, A. M. P. et al. Development and validation of a viagrammatic scale to assess the severity of black rot of crucifers in kale. Journal of Phytopathology, v. 165, n. 3, p. 195-203, mar. 1, 2017. Available from: <https://onlinelibrary.wiley.com/doi/ abs/10.1111/jph.12550>. Accessed: Mar. 2, 2017. doi: 10.1111/ jph. 12550 .

ORTEGA, S. A. et al. Diagrammatic logarithmic scales for assess the severity of spotted leaves and calyces of roselle. Revista Mexicana de Fitopatología, v. 34, n. 3, p. 270-285, sep. 2, 2016. Available from: <http://www.scielo.org.mx/pdf/rmfi/v34n3/20078080-rmfi-34-03-00270.pdf>. Accessed: May 2, 2017. doi: 10.18781/r.mex.fit.1606-6.

PRICE, T. et al. A quantifiable disease severity rating scale for frogeye leaf spot of soybean. Plant Health Progress, v. 17, n. 1, p. 27-29, 2016 Available from: https://apsjournals.apsnet.org/doi/ pdf/10.1094/PHP-BR-15-0054 . Accessed: Apr. 12, 2017. doi: 10.1094/PHP-BR-15-0054.

RUEDA, K. R. et al. Differential organ distribution, pathogenicity and benomyl sensitivity of Colletotrichum spp. from blackberry plants in northern Colombia. Journal of Phytopathology, v. 165,n. 4, p. 246-253, 2013. Available from: https://onlinelibrary.wiley. com/doi/pdf/10.1111/jph.12040\#accessDenialLayout. Accessed: Feb. 09, 2017. doi: 10.1111/jph.12040.

VILLEGAS, C.; ALBARRACÍN, W. Aplicación y efecto de un recubrimiento comestible sobre la vida útil de la mora de Castilla (Rubus glaucus Benth). Revista Vitae, v. 23, n. 1, p. 202-209, dec. 2016. Available from: <https://aprendeenlinea.udea.edu. co/revistas/index.php/vitae/article/view/25235/20784103>. Accessed: Jun. 2, 2017. doi: 02-20910.17533/udea.vitae. v23n $3 \mathrm{a} 06$. 